\title{
Unthinkable to Acceptable: How Stories can make Controversial Ideas More Mainstream
}

\author{
By Chris Underation ${ }^{*} \&$ Rachael Graf ${ }^{ \pm}$
}

\begin{abstract}
Though it has recently fallen on difficult times though the loss of land the death of its leader, The Islamic State is a brand of Islam that styles itself as the new caliphate. ISIS fights for the liberation of the Sunni faithful and claims to be the leader of the world's Muslim population. Westerners and others who oppose ISIS have used a good deal of ink trying to explain what gives this group its power to engage the imagination - is it the extreme violence it uses on the battlefield, or is it the fact that they have boldly claimed a new caliphate and that it is obligatory for the world's Muslims to support them? This paper argues that the power of ISIS comes from the stories it tells. These stories are assessed according to the paradigm of Jim Signorelli's StoryBranding, which explains how stories can become powerful tools of persuasion that create loyal, committed followers that make lasting brands.
\end{abstract}

Keywords: branding, caliphate, Islamic State, marketing, terror.

\section{Introduction}

Since declaring itself a caliphate in June 2014 (Ford, 2016), the movement known as the Islamic State in Iraq and Syria or as the Islamic State in Iraq and the Levant in the press (hereafter referred to as ISIS), has drawn the attention of nations around the world because of its boldness and rapid territorial and philosophical expansion. Although the group has had reverses on the battlefield and lost a good deal of its land, observers note the group seems to continue even when ISIS does not prevail on the battlefield (Vick, 2016).

The self-proclaimed caliphate has been reduced to a handful of villages in the Syrian desert, but the "virtual caliphate" fights on, a diminished but still formidable presence focused on rallying the group's followers in the face of crushing military defeats. (Warrick, 2018a, para. 5)

From where does this growth - or sense of growth - come? It comes from the narrative ISIS has created and communicates to its prospective members. ISIS has a sophisticated, professional storytelling arm that uses historic images, sleekly produced video, and social media to reach out to people in order to sell them on the ISIS brand (Byman, 2016; Tome, 2015; Von Drahle, 2015). This is in stark contrast to earlier groups similar to ISIS. These groups allowed the media to shape and carry their message, often releasing grainy videos or audio for the media to use (Bloxham, 2011). This did not allow these groups to

\footnotetext{
*Associate Professor, Assistant Dean of Academic Affairs, Scripps Howard School of Journalism and Communications, Hampton University, Hampton, Virginia USA.

${ }^{ \pm}$MA Candidate, Liberty University, Lynchburg, Virginia USA.
} 
extend their reach in the way that ISIS has due to the fact that these groups were unable to control their own story (Brooking \& Singer, 2016). ISIS can. The ease and portability of modern media technology that allows information to be created and released quickly is a new thing that is helping the movement develop an international brand.

(ISIS) was originally built around seasoned veterans of the Iraqi insurgency, who were joined by a new generation of millennial recruits. A...study by the New America Foundation found that the average age of Westerners who travel to join ISIS is 24-they've grown up with Facebook, Twitter and Instagram. Working together, these battle-hardened jihadists and social media savvy recruits have developed a loose framework that turns social media into a potent weapon of war...What ISIS has discovered - the very weird, effective new way of war-is not a novelty or a one-time thing. ISIS may have been the first to wield this potent mix of social media, terror and war, but it will not be the last. (Brooking \& Singer, 2016, pp. 60-61)

ISIS has created the template of war-as-unfolding-individual-story, and the stories are creating adherents who may travel to them or who may decide to remain where they are to carry out the group's mission because they resonate with the ISIS story (Calabresi, 2015-2016). This new template is different from traditional propaganda efforts, because the mode of communication is not one-to-many, trying to evoke emotion that creates a group feeling without any real ability for that group to communicate with the source of information (Pratkanis \& Aronson, 2001). Instead, the new template is focused more on single prospects who hold particular worldviews or who harbor certain feelings about the interplay between nations, governments and religion (Phillips, 2014).

Connecting to individuals in this way is not just something that happens by chance. It is part of a process that marketing expert Jim Signorelli (2014) calls StoryBranding. This study will examine the ISIS communication effort to show how they are using the aspects of StoryBranding to extend their power by connecting to individual prospects who are willing to identify with the group's story and adopt it as a part of their personal identity.

\section{Research Objective and Method}

Free societies have sometimes been challenged by the rise of regressive ideas. As hinted earlier, these ideas often come on the scene with great power. The purpose of this study is to help aid understanding about why and how these kinds of ideas gain a foothold against the classical liberal beliefs of western society.

In order to answer this question, the study will borrow a paradigm from product marketing. The trafficking of ideas across wide geographic distances and cultures requires a commonality of communication. The paradigm that best serves this need is known as StoryBranding (Signorelli, 2017). This paradigm provides a clear, step-by-step approach that explains how stories carry deep meaning and become sticky in the mind and heart of particular prospects. It is 
the intention of the research to show how this process works when selling any idea, no matter how antithetical to basic society beliefs that idea may be.

The paper then examines the literature surrounding ISIS and how they communicate their ideas across cultures and languages, even though they are now considered only a virtual caliphate (Warrick, 2018a). Using examples from the media and a variety of other media types, it is the goal of this paper to illustrate how stories can make ugly realities seem normal, and even enticing, as they move through the StoryBranding paradigm. ISIS has grasped the reality that we live in a post-fact world (Fukuyama, 2017). Facts are not the ultimate decider when it comes to what ideas are accepted and which are not. Today it is feelings and impressions that draw us in and that move people to engage with an idea or philosophy that could alter the path of his or her life.

Though ISIS likely is not familiar with the ideas of Signorelli, the organization has been able to use these ideas instinctively and with great success. In order to set the stage for this study, it is best to turn to an explanation of StoryBranding and how this paradigm explains and amplifies meaning.

\section{StoryBranding}

The StoryBranding process has six main steps that help bind an individual to an organization, idea or product. The six are the Backstory, the Brand's Inner Layer, the Brand's Outer Layer, the Obstacles, the Prospect's Outer Layer, and the Prospect's Inner Layer (Signorelli, 2014). Each of these adds up to a portion of the overall brand story that ISIS tells, and at each level the prospect is drawn more deeply into the story.

The Backstory provides a prospect with a sense of where the brand has been and where it is today. This is also the place where the brand will differentiate itself from any other brands that are similar to it (Signorelli, 2014). This includes important historical points in the brand's history and providing a sense about what the goals of the brand may be for the future. This provides the context for everything the brand is and does.

The Brand's Inner Layer is essentially the soul of the brand, which is much deeper than a mere mission statement. Here, a brand states what foundational belief it promotes. If it has an archetype that it connects with, then this is the place that it is set forth. (Archetypes will be discussed shortly.) This meaning comes from the top of the organization (not via focus groups), and it sets forth this "sense of self" directly (Signorelli, 2014, p. 90).

Signorelli (2014) says that in order to succeed, the inner layer has to be authentic to what the brand actually is. This makes the brand the hero of its story - the person or thing that resolves the tension that is created through the brand's backstory. If the brand can be seen as the best way to resolve the tension, it stands a good chance to win over prospects who feel or accept the same tension. Heroes win supporters in the same way, because they are seen as champions who triumph over obstacles, allowing people to affiliate with a winner.

Brands may also embrace an archetype to support the hero. Archetypes may 
also be used in place of a brand's backstory if that story lacks tension that needs a resolution. These archetypes are The Purist (one who is wholesome, ethical and virtuous); The Pioneer (an individualist who seeks adventure and, in that, freedom); The Entertainer (a fun-loving free spirit who lives in the moment); The Conqueror (noble and meets adversity head-on, relentless, resilient, and confident); The Wizard (seeks to change the ordinary into the extraordinary, embraces mystery, thrill and novelty); The Protector (puts others first, compassionate and generous); The Seducer (romantic, intimate, strong sex appeal); The Imagineer (an innovator and dreamer who wants to creatively express his vision of the world); The Emperor (the boss who exerts authority over others); The Rebel (unsatisfied with the status quo, protects self-expression); The Source (the all-knowing provider of knowledge and expertise); and The Straight Shooter (no pretense and no nonsense, friendly and informal) (pp. 102-113). The best brands know what their inner layer is and they do not shy from it, understanding that they will attract some prospects and turn away others. Brands that embrace StoryBranding do not try to be all things to all people.

The Brand's Outer Layer is an explanation of the brand's unique advantages and benefits. The important thing is that this explanation has to fit tightly with the inner layer so there is consistency of conviction (the inner layer) and how it publicly speaks of itself (Signorelli, 2014). This is sometimes done by developing an I Am/We Are statement that sets forth a clear sense of the benefits of the brand.

The next step is assessing the obstacles that impede an individual from affiliating with the brand. These obstacles can take on a variety of disguises. Some of them are external obstacles, such as culture, economics, consumer attitudes, and public perception (Signorelli, 2014). Other obstacles are internal, the politics of the organization, logistical issues, and competition from similar brands. StoryBranding considers these things, but it also looks at obstacles a bit differently.

StoryBranding wants to move people past simple awareness of the brand and knowing reasons for its general superiority to a personal affiliation with the brand. The first obstacle in StoryBranding is developing brand function awareness. Essentially, brands have to let people know that they exist. Once this is accomplished, the prospect moves to the second obstacle-knowing why the brand is superior (Signorelli, 2014). This means that a prospect has some awareness of the things that make the product better than competing offerings.

The third level obstacle that StoryBranding seeks to overcome is a lack of association with the brand. Signorelli (2014) describes this as "the confidence obstacle" (p. 151) because the goal is to move people to develop positive associations with the brand. These associations should be strong, not mere assent. Once people have a confidence in the brand - a certainty that it is what it says it is and does what it says it will do-it becomes easier for a prospect to develop affiliation with the brand.

Affiliation is the fourth obstacle to be overcome. Once there is confidence in a brand, people will be more easily moved to resonate/affiliate with it. To get here, Signorelli (2014) writes:

To be achieved, affiliation has to be felt by the prospect. Resonance cannot be forced...To get through the obstacles to making a strong Level IV connection the 
things the brand stands for (the inner layer) must link with the things that the prospect considers to be personally important. It must represent an important human value that the prospect readily identifies with. (p. 153)

The fifth step in StoryBranding is to define the Prospect's Outer Layer. This requires having a sense of the descriptive attributes that define the prospectthings like the demographics. Along with this, a brand also has to know the most functional needs of the prospect (psychographic measures such as respect, honor, happiness, peace, and so forth) so that it can frame these needs for the prospect. It is also vital that the functional needs identified by the brand are consistent with the brand's outer layer.

The final step is identifying the Prospect's Inner Layer. Just as the prospect's outer layer has to be consistent with the brand's outer layer, the prospect's inner layer has to be consistent with the brand's inner layer. At this stage, the brand should define the prospect's most functional need and speak to it. This functional need is the core of the prospect, and if it matches the core of the brand it often follows that a Level IV connection-affiliation with the brand-develops, making the prospect and the brand one in a practical and emotional sense. Brand affiliation is the ultimate goal, but it all begins with a story that is properly constructed. Signorelli (2014) says:

Clothe truth in a story in order to make your truth real for others. Good stories don't point a finger at us while telling us how to think and feel. Rather, they invite us to think and feel for ourselves...successful brands don't rely solely on facts, they want us to know about their products. They place a good deal of emphasis on "clothing the truth." Specifically, they promote their product claims by wrapping them in the "clothing" of the causes they support and in life causes their audience can identify with. (p. 33)

Scholars Samuel Perry and Jerry Mark Long (2016), in their study about how ISIS convinces people to embrace martyrdom, have found ISIS engages in this StoryBranding practice. Their approach does not command or in any way imperatively state that one must become a martyr. Instead, one is invited to be great and to leave a story of honor behind for others to follow, and the way to do this is to become a martyr.

ISIS offers potential adherents the opportunity [emphasis added] to enter into a narrative that specifically recapitulates Islamic history and develops a compelling new identity based on that history. That powerful inducement speaks to those who believe themselves dislocated from their own cultural milieu...sometimes as a result of this alienation, many jihadists find individual identities within the constitutive, instrumental and mythic appeals found in ISIS messaging. (p. 1)

Before moving to the assessment of ISIS's overall StoryBranding, the reader will notice several aspects of Signorelli's steps in the comment of Perry and Long. There is the backstory, where prospects are invited to take part in the narrative spun by ISIS. This is followed by the ISIS inner layer where they promise a new identity for those who are faithful, even to death; and the ISIS outer layer promises 
a role - and ultimate glory - in the history of the culture that has rejected them, thus showing the culture they did not recognize courage and truth; the prospect's outer layer is the functional need of recognition and purpose, which fits with the offer made by the ISIS outer layer; and the inner layer of the prospect (recognition and purpose) connects to the ISIS inner layer that promises a new identity and new hope for those who are faithful enough to join with ISIS.

\section{StoryBranding the Islamic State}

\section{The Backstory}

When it comes to an organization's backstory, there has to be verifiable history in the myths in which the group attires itself. In the case of ISIS, its backstory is not about its actual origins in the late 1990s (Bilger, 2014; Byman, 2016; Gartenstein-Ross \& Jensen, 2015; Kavalec, 2015), it is about the prophetic myths they have appropriated and molded into a story.

Robert Rowland and Kristen Theye (2008) point out that terror organizations and the actions they undertake are fundamentally rhetorical in nature. Because of this truth, the backstory ISIS has crafted to send out into the world is carefully sourced, closely connected to well-known aspects of Islamic history, and looking forward to a time when the mostly corrupt state of present Islam is redeemed and made pure again so that the return of the Mahdi (the end-of-times redeemer of Islam) can take place and usher in a period of peace (Chua, 2015).

The first step in this plan came when ISIS declared itself a state under the leadership of Caliph Ibrahim (Ford, 2016). By taking this step, the late Ibrahim Awwad Ibrahim-al-Badri had to prove that he fit the Islamic prophecies that claim the End Times will be ushered in by a man descended from the Prophet Mohammed. Pointing to his nom de guerre-Abu Bakr al-Baghdadi alQuraishi-al-Badri made his case.

This name ties to well-known Islamic history on three levels. The original Abu Bakr was the closest friend of Mohammad, and Abu Bakr was the first caliph. Bakr is widely considered the one who put Islam back on the "straight path of early Islam" (Ford, 2016, p. 17). The middle name al-Badri selectedal-Baghdadi-potentially resonates, because the goal of ISIS is to revive the caliphate and rule from Baghdad as the pure Abbasid caliphs did during the "golden age and building boom... an era of historic significance and pride that Muslims have for this period of history," and the name is also a message that the city will ultimately be theirs (p. 20). The last name, al-Quraishi, was selected because Mohammed was from the Quraish tribe (p. 19). Supporters of the ISIS leader have given out a genealogy that allegedly proves Baghdadi is descended from Mohammad, even though his real name and place of birth (Samarra) is public record (p. 18).

Symbolically, ISIS also advances under a black flag, which has long been considered a prophetic symbol of Islam's advance in the world (Gunther, 2014). In one iteration of its English-language magazine, ISIS has shown its flag flying over 
well-known buildings and parts of the world, such as the Vatican (Roche, 2017).

As such, the black flag, a recurrent motif in jihadist images, is heavily charged with meaning: The black banner is connected to a prophetic tradition, which according to the renovators of "genuine" Islam would arise and bear the black flags that would led them to a final victory against the rule of tyranny and restore justice. (Ford, 2016, pp. 41-42)

This flag serves as a symbol that a purer form of Islam will rise and reclaim the religion's past glory, which is the glory of Islam's founding when it was pure and undefiled. ISIS is the group that takes the challenge seriously, even going so far as to kill fellow co-religionists who do not join with them.

Islamists regard the Quran and (the sayings of Mohammed) as God's will and believe that most of the countries that call themselves Muslim are far from adhering to them. Those countries that fail to implement Muslim law are instead seen as corrupt, guided by leaders who have defiled themselves through contact with non-Muslim nations of the West. Consequently, ISIS believes that reordering society in accordance with the God-given tenets revealed in the Quran and the (teachings of Mohammed) is the antidote for the moral bankruptcy of Western society. (Kibble, 2016, p. 29)

The forward-looking message ISIS sets forth in its stories is that it is helping to purify the religion - and the world - for the Islamic eschaton, though J. Y. Chua (2015) wonders if "the Islamic State's propaganda is motivated by a genuine belief that the end-times are imminent, or if it is a convenient tool for indoctrination" (p. 8).

The core promises of the Islamic State's apocalyptic argument are as follows: the world as we know it will come to an end; the present conflict in Syria represents the beginning of the end times; the Islamic State is on the right side in this dualistic battle between good and evil; and, because they are in the right, joining Islamic State guarantees salvation. (p. 8)

Though ISIS clothes its truth in an Islamic dress, it also sets forth a message for those who are disenchanted with their life and surroundings who may not be moved by strong religious arguments. In the Muslim community, there is a respect and honor for the so-called strong horse, the person who fights and perseveres (Gartenstein-Ross \& Jensen, 2015). ISIS, through its rhetoric and its action, provides an appeal to those who feel disenfranchised.

Many may harken to the group's dynamism - it's actually fighting, not drifting, as many Muslims say their global community has been doing since the last acknowledged caliphate was abolished at the close of World War I. When he established his caliphate in June 2014 ISIS leader Abu Bakr al-Baghdadi's call to arms appealed to the sense of aggrievement that has bedeviled Muslim politics since: "So rush O Muslims and gather around your (caliphate), so that you may return as you once were for ages, kings of the earth and knights of war. Come so that you may be honored and esteemed, living as masters with dignity. (Vick, 2015, p. 14) "

With these messages - a return to truth and dignity; becoming masters of their 
own fate; creating the conditions for the End of Days; being winners; and getting on the right side of history-ISIS establishes its context and the parameters of its brand story. But the question still looms: what is ISIS? What do they claim themselves to be? It is to this question that we now turn.

\section{The ISIS Inner Layer}

In the context of StoryBranding, the inner layer consists of what the organization believes about itself (Signorelli, 2014). The inner layer has nothing at all to do with that people think of or say about the product. The inner layer exists "...for the purpose of arriving at an authentic story, meaning that the management, not the voice of the consumer, should determine what the inner layer is comprised of and that it should reflect genuine, rather than synthetic, values" (p. 89).

Military experts and communication scholars such as David Kibble (2016), Theresa Ford (2016) and J. Y. Chua (2015) point out the ways in which ISIS fails to live up to its religious claims. But inconsistent or not, the inner layer reflects how the organization sees itself and believes what it is in substance. ISIS sees itself as a religious entity that is reclaiming Islam and embracing historic truth; promoting faithfulness and boldness in Islam; with the ultimate goal of bringing glory to God and gaining glory in the world.

ISIS's self-identity, according to scholar Luis Tome (2015), is based in large part on reclamation of the faith. He says this represents the largest part of the group's identity.

Islamic State...wants the Islamic community to return to "pure" ancestral practices, making a clear separation between the true believers and the unbelievers, who are considered to be apostates or infidels. They view themselves as the defenders of the original Islam that the Prophet Muhammad and his companions preached, and they consider that Islam is now under attack by the infidels. (pp. 119-120)

Picking up on this theme, Christoph Gunther (2014) writes that the attack on Islam means ISIS's actions cannot be defensive, they must be offensive. ISIS believes today's Muslims are "under siege and they have to actively fight back in order to renovate the Islamic mission" (p. 42). Though western nations see ISIS as an aggressor, ISIS believes they are fighting western corruption in their attempt to return Islam to a more authentic place, which ties directly to the ISIS use of historic names and images.

The group's claim for genuineness is connected to the claim for the Prophet Muhammad's spiritual and physical heritage. This notion...is signified by the black flag and the second part of the writing on it...whose upside-down writing order is explainable by its deliberate resemblance to the Prophet's seal. Using the seal in this way symbolically transfers the Prophet's authority as a political and religious leader upon the Islamic State of Iraq. (pp. 46-47)

As a self-declared state and keeper of historic truth, the things the group says through its local leaders and media outreach allow it to set the parameters for 
what it means to be a faithful Muslim - even when these actions are not in clear accord with the Quran. As opposed to being a problem for ISIS, the things it defines as true (but that cannot be defended scripturally) make it appear strong and bold and help clothe the movement with a sense of honor.

Flagrant acts of barbarity bestow on them a moral legitimacy; in the eyes of the local public, these ragtag groups and their fanciful reenactments of precolonial purity represent acts of moral reclamation. Unlike their vastly corrupt governments whose leaders placate the international community for fear of losing the aid packages with which to pad their private fortunes, these groups stand apart... Western horror represents not moral pressure to change a local practice, but rather the affirmation of its purity and rightness. (Zakaria, 2015, p. 24).

All of these ideas represent the core of ISIS. From these convictions, the group communicates its messages to its potential prospects. This communication happens through the organization's outer layer, which is the face it puts forth to the public. In order for these messages to be effective, they have to connect with the inner layer. Successful messages in StoryBranding do not bring into existence something that does not exist. It taps into and amplifies what already exists within its prospects. As Signorelli (2017) writes: "The best stories agree with what the audience already believes" (p. 36).

\section{The ISIS Outer Layer}

The backstory of the brand provides the context for all the actions the brand takes. The inner layer is the convictions the brand holds. The outer layer is the plots and/or themes the brand deploys in order to clothe its convictions in truth (Signorelli, 2014). Some of the themes ISIS uses will be familiar from some of what was detailed under the Backstory. It is also at this phase that the brand story of an organization or product begins to take shape.

According to communication scholars Megan Hastings and Kenneth Rogerson (2016), the best stories are focused but not prescriptive. In a paper that offers some suggestions about how to contest ISIS stories using social media, they are critical of western efforts to undercut the ISIS brand story, because the message typically amounts to a direct statement that terrorism is bad. Even direct attempts to destroy the networks that carry the ISIS message do not win the day, as a recent attack against the group's media center in Amaq show (Warrick, 2018b).

The mixed success of the Amaq takedown effort reflects the challenges and frustrations faced by governments worldwide as they try to stop violent extremist groups from using the Internet to recruit and radicalize. While the Islamic State has been defeated militarily in Iraq and Syria, the group's online empire-its "virtual caliphate" - has shown remarkable resilience, producing, with few interruptions, a steady barrage of propaganda videos and communiques, despite cyberattacks, territorial losses and the deaths of dozens of top officials and technicians in its media division. (para. 5). 
ISIS's effort is much stronger and more powerful, they say, because it is "flexible and has a more compelling narrative" (Hastings \& Rogerson, 2016, p. 22 ). The flexibility comes from the variety of media ISIS uses and the various stories they tell prospects.

One of the stories is the evocative story of the Gray Zone. This story connects to the inner layer value of purity. As ISIS sees things (and sets forth the story), there is a vast Gray Zone that is made up of societies where true religion and false religion exist together.

The gray zone turns out to be IS's term for any society in which Muslims and non-Muslims coexist. It sounds simple because it is. (Islamic State) sees the world as black and white and abhors the middle group - the gray zone-where everyday life is lived. (Vick, 2016, p. 6)

True Islam, ISIS claims, cannot be restored until a time comes when people take a side for the right and true or against it (Chua, 2015). In order to help individuals see how the right and true is advancing, ISIS has adopted a number of images and symbols to mark their mental territory. We have earlier mentioned the use of the black flag, which is an apocalyptic symbol that marks the advance of ISIS and truth. Within this territory-and through the internetnasheeds are often used to help reinforce the group's message and stories. Ford (2016) explains that nasheeds are a form of Islamic devotional music that would be roughly similar to contemporary Christian music. These chants are effective in getting the message into the memory of the listener because songs and lyrics are easier to remember than words alone (Mitchell, 2013). They also drive home the themes ISIS wants people to remember.

The reason this works so well is due to the lack of knowledge of their religion among many Muslims. In the first ISIS iteration of a sleekly produced Englishlanguage magazine (which went by the title of Dabiq, named after the city where Islamic scholars believe the final battle of good against evil will take place), they write that many adherents to the faith "...are ignorant of their religion and they thirst for those who can teach them and help them understand it" (Kalifah, 2014, p. 11). This is the brand as hero of its story that was mentioned earlier. In the case of the inner layer convictions and the outer layer stories, the answer to the problems that ISIS sets forth in its simple way is that support for or affiliation with them will bring a positive resolution to the tensions they feel.

On social media, ISIS operates on several levels. On one hand, they reassure people within their territory that life is normal by announcing the opening of public buildings and showing the services they offer to people. Some of it is an offshoot of western social media silliness - such as "Cats of Jihad," which allows fighters to pose with their cats and weaponry (Brooking \& Singer, 2016). This shows that ISIS is not just angry and dangerous but that it can have fun too.

The success of these stories flows from the simplicity with which they are told. There is a Gray Zone, there is normalcy within the ISIS state, there is benevolence as those who desire to know the truth are taught it, and there is a reason that Islam is not now great-it is being undermined by those who do not 
believe. The power in stories like this is that they invite people to apply them to their personal experience - as Signorelli (2014) says, "...stories intend to sell us something. Whether it has to demonstrate the importance of love, courage or freedom, some human value always underlies the reason a story is told. But the beauty of stories is that they reveal truth; they don't hit us over the head with it" (pp. 4-5).

\section{Obstacles}

As brands strive to make disciples of their prospects, there are always obstacles that have to be overcome. ISIS is no different. As they strive to gain adherents and create a caliphate, they face challenges. Some of these are external-such as the resistance from the West and from Muslims who do not agree with their interpretation of the Quran (Shahi, 2012). Some are internal, such as infighting due to scarcity of resources as a result of the decline in oil prices that funded most of their war effort (Browne, 2016; Warrick, 2018a).

In StoryBranding, obstacles are whatever gets in the way of converting people to a sense of resonance with the brand. Resonance is not simply intellectual agreement, it is a feeling that a prospect develops for a product or organization (Signorelli, 2014). As the previous section demonstrates, ISIS has gone to some lengths to separate itself from the typical terror organization. It wants to show a normally functioning state that has many of the challenges of a functioning state, but that can deliver on its promise to create a true Islamic utopia (Kavalec, 2015).

Signorelli sets out four main obstacles that brands have to overcome in order to get to the point where a prospect feels resonance. In the case of an organization like ISIS, the feelings of the people who are unpersuadable are not taken into account. They are focusing on the people who are open to the story they are telling (Walt, 2015).

ISIS has already gotten past the first obstacle - a lack of product function awareness (CBS News, 2016). Signorelli (2017) says the purpose at this level is to make people aware of the primary function of the brand. Generally speaking, ISIS is a known brand because of its primary goal, which is to wage jihad. It has also gained general awareness for most of its various personasmaker of war, oil broker, state actor, and so forth (Trofimov, 2016).

At the second level, a brand has to establish some sense of what makes it superior to its competitors. In the places where it held land, ISIS told a different story that connected to its conviction to restore Islamic society and culture. ISIS tells this story by focusing on topics like the environment and healthcare, in addition to other projects.

ISIS claims it has committed itself to caring for the land in the territory it occupies. Time magazine reports that, in Mosul, citizens can be fined for failing to dispose of their trash properly (Cambanis \& Collard, 2015). If citizens refuse to pay the fines, they can be detained. These environmental efforts are in keeping with its mission of practicing a pure, redeemed form of Islam. Although the Quran instructs all Muslims to care for the environment, 
many Islamist groups - such as the Muslim Brotherhood, Hezbollah, and Hamas - have failed to carry out the dictates of the Quran (Yildirim, 2016). In this, ISIS distinguishes itself from other Islamist factions because they give off the sense they are true believers, down to the faith's smallest points.

Additionally, ISIS has gone to great lengths to provide healthcare for its members and for those living under its regime. In June 2015, ISIS began calling for Westerners - especially medical personnel-to join their cause (Vogel, 2016). Approximately 30,000 men and women left their home countries to serve as health care providers for ISIS that year, and "a small but alarming number" of them were doctors or medical students from the United Kingdom, the United States, Canada, Australia, and Israel (Vogel, 2016, p. 177). Though the reasons for Westerners joining ISIS are varied, many are attracted by ISIS's utopian ideals. Thus, some Western recruits view ISIS as promoting a "social justice" agenda (Vogel, 2016, p. 178). CNN reports that ISIS issues also birth certificates, runs maternity wards, and has mobile vaccination clinics (Shubert, 2015).

This is one thing that distinguishes ISIS from groups like the Taliban, which forbids vaccinations. Polio is a problem in Pakistan because the Taliban believes the vaccines are a forbidden substance. The Taliban forbids all female education. But ISIS allows girls to go to school, albeit in a segregated environment. (Shubert, 2015)

ISIS also conducts complex fund-raising operations and runs construction companies that develop infrastructure in cities like Raqqah and Mosul (Berti, 2015).

According to Lorne Dawson, codirector of the Canadian Network for Research on Terrorism, Security, and Society, "only about 10\%" of ISIS's social media content is concerned with warfare (qtd. in Vogel, 2016, p. 178). That means the other 90 percent of ISIS's social media is devoted to nonviolent causes and campaigns, such as environmentalism and healthcare. ISIS reinforces the idea to its prospects and local critics that it is not just a backwater terrorist organization of cave-dwellers, but a reputable organization dedicated to a just cause.

The third obstacle is the confidence obstacle. At the first two levels, people can make a simple mental connection, but here emotions begin to become involved (Signorelli, 2014). Thinking back to the previous section, the "Cats of Jihad" social media presence and the stories that report on the normalcy of life under ISIS governance is an attempt to develop a third level connection with a prospect. At this level, a prospect makes a positive emotional association with the brand. This level creates a bit of the halo effect for a brand, where the other things it connects to are viewed positively. This is seen in the outreach to recruit fighters, where ISIS tries to show how much better life is with Islamic State when compared with their home nation (Trofimov, 2016).

Tunisia's functioning democracy remains an exception: Arab Spring revolutions elsewhere have either turned into civil wars, as in Syria, Libya or Yemen, or were 
crushed by re-established dictatorships, as in Egypt. Yet even in Tunisia, popular disappointment is spreading, said Moncef Marzouki, a human-rights activist who served as democratic Tunisia's first president from 2011 and until the end of 2014. While the country's Jasmine Revolution ushered in democracy, it failed to spur economic growth or curb rampant corruption, he said. "Why do we have educated people, people with jobs, who go to ISIS?" wondered Mr. Marzouki. "It's not the matter of tackling socioeconomic roots. You have to go deeper and understand that these guys have a dream - and we don't. We had a dream-our dream was called the Arab Spring. And our dream is now turning into a nightmare. But the young people need a dream, and the only dream available to them now is the caliphate." (para. 8-10)

With a positive emotional attachment driven by circumstances, the fourth level connection can take place. These are the people who resonate with a product to the point where they personally identify with it. To paraphrase what was quoted earlier in the paper, this happens when the brand taps into a belief that the prospect considers personally important - and that the prospect readily identifies with.

ISIS has orally and digitally proclaimed its message and its name to the point that, around the world, educational institutions, boutiques, and organizations with the name ISIS have had to spend millions of dollars rebranding or suspending use of the acronym, despite claiming it years before the group in some cases (In a Name, 2016). With a handful of annual reports, glossy magazines that were published through 2017 (Warrick, 2018a) and hundreds of Twitter channels all around the internet, ISIS has gone far beyond the obstacles of brand awareness and comprehension. It seems everyone knows ISIS, what they are about, and how to connect to them if they wish to do so.

As with the brand's inner layer, the obstacles have to be wrapped into a communication strategy that answers or somehow overcomes these obstacles. Doing this is not always as complicated as it may sound, which we will see as we look into the next step in StoryBranding - the prospect's outer layer.

\section{Prospect's Outer Layer}

The outer layer of the prospect consists mostly of the traditional measures marketing and advertising use-demographics and a flat definition of the individual (Signorelli, 2017). ISIS has adopted an integrated communication effort. It does not merely communicate within the area where it dominates, it also reaches out, providing communication in English and other languages in order to project power (Vick, 2016).

In the Middle East, ISIS is the voice of the Sunni Muslim (Byman, 2016). The ISIS inner layer and interpretation of Islamic teaching flows from Abu Bakr, the original Sunni (Ford, 2016). As such, ISIS looks to consolidate its power first in these areas of the Middle East and those areas that are Sunni controlled. This group is their primary local audience. However, in eliminating the gray in Islam, ISIS has slightly hampered its ability to persuade prospects to embrace the brand. 
The Islamic State's decision to declare a caliphate and demand that all Sunnis swear allegiance to the caliph, Abu Bakr al-Baghdadi, was deeply divisive and a number of tribal sheikhs refused to pledge allegiance to Baghdadi. (GartensteinRoss \& Jensen, 2015, p.F 108)

As we will note with the ISIS outreach to the West, the group acts as the hero who can come to the aid of Muslims who are unhappy with their lot in life (Trianni, 2015; Zelin, 2014). Rather than attempting to solve this dissatisfaction through governmental means, ISIS offers a different approach.

(Islamic State) follows al-Qaeda's precedent in challenging the most foundational principles of today's global order, in which political authority is institutionalized in a universal system of sovereign nation states, rather than anchored in a common system of religious authority. The vision of a revived caliphate may present to Westerners as an absurd totalitarian fantasy. But it taps into a deep disaffection with a world order that an angry minority of Muslims regard as the product of Western imperialism, designed to keep the Islamic community estranged from and God and from one another, as well as a hostage to a toxic Western secular modernity. (Phillips, 2014, pp. 496-497)

In the West, the ISIS story attempts to "crowdsource jihad," as Calabresi (20152016, p. 50) terms it. The group actively works social media to extend its brand, attempting to move prospects through each of the obstacle levels to affiliation.

This effort appears to be working, according to Holly Yan (2015). In her assessment of who is responding to the ISIS message, she notes that about 3,500 Westerners have joined with the group. Roughly 200 of those are Americans (Berlinger, 2015). Generally speaking, ISIS puts forth messages that aim to connect with those who feel disconnected from Western culture. This attempt to connect remains even if the prospect returns to his native country.

It is highly likely that even as the territorial caliphate shrinks and is increasingly denied an overt presence, its leadership will look to supporters overseas, including returnees, to keep the brand alive. Most returnees will be unlikely to experience anything in their lives at home that matches the intensity of their experience as a member of ISIS, whether or not they were fighting on the front line. If on return they begin again to feel as rootless and lacking in purpose as they did before they left, then they are unlikely to settle back easily into a "normal" life, and as IS increases its external campaign, both through action and propaganda, returnees may be particularly vulnerable to contact from people who were part of the network that recruited them, or appeals for help from ex-comrades in arms. It seems probable that the influence and involvement of returnees will grow as their numbers increase. (Barrett, 2017, p. 15)

In this way, ISIS is also engaged in a soft war, looking back to the earlier statement that the work of terror groups is foundationally rhetorical in nature. They are engaged in a contest against the Western narrative that satisfaction comes from freedom and individuality.

As these actors seek to construct and communicate narratives about their place in the world using new media, contestation becomes inevitable as they seek to 
establish positions in the international system as they seek to shape the behavior of other actors. The contestation occurs along.... a spectrum of persuasion. (Hastings \& Rogerson, 2016, p. 4)

This persuasion often takes the form of granfalloons, drawing people into a shared community or identity based on ephemeral definitions (Kavalec, 2015). As ISIS recruiters troll for prospects who have a light connection with their physical community, they strive to draw these individuals into an online world that is shaped by ISIS philosophy.

For the traumatized children of war-torn regions, the message might be: join us and kill your enemies before they kill you. For the disaffected loner in a European or American suburb, it might be the fellowship of a movement of strong Muslims. For a history-minded dreamer it might the promise of restored Islamic greatness. (Von Drahle, 2015, p. 54)

Just as the ISIS narratives are flexible, so are the approaches to their prospect's outer layer. Reports show that people from about 90 nations have been drawn to ISIS, which makes it a more internationally diverse unit than the one that is fighting against it (Cohen, 2015). But since the ability to travel to join with ISIS has been greatly restricted,

(A) growing number of them have been urged to wage jihad in their homelands. "If you are not able to find an IED or a bullet, then single out the disbelieving American, Frenchman or any of his allies," an IS spokesman announced last year. "Smash his head with a rock or slaughter him with a knife or run him over with your car." (Von Drahle, 2015, p. 54)

The tight fit between ISIS's inner layer, outer layer and the prospect's outer layer achieves what brands typically hope for - a consistent, well-tailored message that results in a regular flow of like-minded prospects who have set aside or minimized the various obstacles the brand faces so they can move toward the fourth level, affiliation.

\section{Prospect's Inner Layer}

It may seem as if connecting to the prospect's outer layer represents victory for a brand. But it does not, because the ultimate goal is not merely to share an idea in common with a person or a brand. The final goal is to develop shared values that add up to identifying with a brand. This identification takes the form of a similar world view, life priorities, values, and aspirations (Signorelli, 2017).

J. Y. Chua (2015) writes that the ISIS narrative that appeals to Muslims frustrated by being marginalized by their governments and by more powerful nations also appeals foreigners, though for slightly different reasons.

Many foreigners who join Islamic State are seeking to reconcile the contradictions of secular society - the data of life - with Quranic visions of the good life - the model for life. Hence, joining the apocalyptic struggle of the Islamic State is an attractive option. (p. 10) 
The fact that a story can appeal to two different individuals who are operating within very different contexts is evidence that ISIS has crafted a powerful, flexible narrative, but not so powerful that it is a one-way street. There is room within the narrative for people to hear the case ISIS makes and to apply that case to their personal beliefs and context. The response to the story is not mandated by ISIS, but it is implied, helping the prospect make his or her own decision. This makes the decision the prospect's, and we tend to embrace and build our identity around the decisions we believe we freely make because we tend to strive for internal consistency in beliefs that we publicly affirm (Cialdini, 2008).

Once internal consistency rises, the belief or series of beliefs that we try to make consistent becomes our hermeneutical grid. It is through this grid that we begin to interpret the things around us, and this, in turn, colors our view of the world.

The act of influencing others and winning them over requires some counterintuitive actions. The "Cats of Jihad" social media project is one attempt to lighten things up so the message does not become gloomy or oppressive. But ISIS does other counterintuitive things. For example, an ISIS recruiter on Ask.FM's website discussed the best beard oils and published memes such as the photo of him and his brother in combat gear with the text "This is our Call of Duty, and we respawn in Jannah" emblazoned across it (Segall, 2014). These softer touches put a human face on a brand that others are trying to brand as inhuman. For someone who is being converted to a level IV connection with a brand, the counter message about the inhumanity of ISIS is not in accord with that they have seen from the organization. The result is that they tend to see the message that does not fit with their experience as affirmative evidence that the group is being persecuted by opponents (Kibble, 2016). When one's tendency is to defend a brand in this way, it is solid evidence that an individual has developed resonance with it.

\section{Conclusion}

The success of ISIS in the area of communication is due to the quality of the stories it tells. Thanks to the work of earlier terror groups, ISIS has been able to consolidate dissatisfaction with nations like Russia, the United States, the leadership vacuum following the fall of the Taliban in Afghanistan and Saddam Hussein in Iraq, into a series of stories that resonated with a reasonable minority of people from all over the world (Moutot, 2016).

A number of military analysts and communication scholars misapprehend the power of ISIS's communication efforts. They believe the group's power is in cynically telling lies to gullible people or that their power comes from being first to colonize social media and short form video for purposes of jihad.

Neither of these takes into account two important facts. The first is that ISIS is telling the truth as it sees it. This is not to say the group is virtuous and telling the full truth. ISIS fully believes the things it is doing, and their assessment 
of the facts is their identity.

The second key fact is that the power of their story comes from the conviction this truth contains (Signorelli, 2014). It is consistency and conviction presented confidently that connect with individuals who have ideas, feelings or experiences that resonate with all or part of the brand's story. If ISIS's actions and words were inconsistent, the actions would undermine the words. But no matter how barbaric their actions may be, ISIS has been consistent in how they speak about these actions. This consistency flows from conviction.

It is also the quality of their story that draws people in. Sleek videos that are often like movie trailers and stories that bear the hallmarks of professional scripting and editing draw an audience (Perry \& Long, 2016).

Muslim and Western nations that wish to counter conviction-driven stories can only do this by telling stories of their own. These stories have to contain an element of hope in them. Though their world is often dark, the stories ISIS has told contain glimpses of a positive dream. Potential suicide bombers talk about the glory that awaits them in heaven, and the wonderful stories of bravery others will tell about them after they die (Perry \& Long, 2016). Recruits are encouraged to take a hand in honoring God by fighting wherever they are (Petroff, 2015).

The power in the ISIS virtual caliphate rests in the power of narrative. The examples in the paper show the ways the organization knows its own soul and the soul of its prospects. This makes it possible for them to develop a connection with certain people that can overcome the alleged power of facts. The StoryBranding paradigm, as it has been explained in this study, shows feelings trump facts.

All of these attributes have allowed ISIS to build a worldwide brand that may endure despite its present reduced state, at least until a more compelling narrative is set forth that can discredit their story (Warrick, 2018a).

\section{Bibliography}

Barrett, R. (2017, October). Foreign fighters in Syria. Retrieved from shorturl.at/kIOQ2.

Berlinger, J. (2015, February 26). The names: Who has been recruited to ISIS from the west? Retrieved from shorturl.at/dkrIO.

Berti, B. (2015, August). The surprising way groups like ISIS stay in power. [Video file]. Retrieved from shorturl.at/oyRSW.

Bilger, A. (2014, May 22). ISIS annual reports reveal a metrics-driven military command. Retrieved from shorturl.at/GKR01.

Bloxham, A. (2011, May 19). Osama bin Laden's past video messages. Retrieved from shorturl.at/lsA19.

Browne, R. (2016, April 27). ISIS internal docs show struggle to retain fighters, cut costs. Retrieved from shorturl.at/KV124.

Brooking, E. \& Singer, P. (2016, March/April). The war of social media: ISIS goes viraland the world. Retrieved from www.popsci.com

Byman, D. (2016, March/April). ISIS goes global: Fight the Islamic State by targeting its affiliates. Foreign Affairs. Retrieved from shorturl.at/fkxTW.

Calabresi, M. (2015-2016, December 28/January 4). Homeland security, ISIS and the fight against fear. Time. Retrieved from shorturl.at/gpsyF.

Cambanis, T. \& Collard, R. (2015, February 26). How ISIS runs a city. Retrieved from 
shorturl.at/hkMP7/.

CBS News (2016, March 10). Docs appear to reveal info on dozens of ISIS recruits. Retrieved from shorturl.at/cghqJ.

Chua, J. Y. (2015). Countering Islamic State's apocalyptic narrative. Journal of Undergraduate International Studies, Fall, 8-16.

Cialdini, R. (2008). Influence: Science and practice. Needham Heights, Ma.: Allyn \& Bacon.

Cohen, K. (2015, April 2). UN report: More than 25,000 foreigners fight with terrorists. Retrieved from shorturl.at/zAI03.

Ford, T. (2016, March/April). How Daesh uses language in the domain of religion. Military Review. Retrieved from shorturl.at/absCJ.

Fukuyama, F. (2017, January 12). The emergence of a post-fact world. Project Syndicate. Retrieved from shorturl.at/gzJ39.

Hastings, M. \& Rogerson, K. (2016, Jan. 8). Battle of narratives: Contesting ISIL's propaganda with social media. Southern Political Science Association SPSA 2016 Annual Conference, San Juan, Puerto Rico.

Gartenstein-Ross, D. \& Jensen, S. (2015, July/August). The role of Iraqi tribes after the Islamic State's ascendance. Military Review, July-August, 102-110.

Gunther, C. (2014). The land of the two rivers under the black banner: Visual communication of al-Qa'ida in Iraq. International Journal of Contemporary Iraqi Studies, 8(1), $35-53$.

In a Name (2016, May 30). What's in a name: Is ISIS too toxic for businesses to use? Retrieved from https://bbc.in/31pVUGN.

Kalifah (2014, July). The return of the Kalifah. Dabiq. Retrieved from https://bit.ly/2Us 2ICi.

Kavalec, T. (2015). From al-Qaeda in Iraq to Islamic State: The story of insurgency in Iraq and Syria in 2003-2015. Turkish Journal of International Relations, 14(1), 1-32.

Kibble, D. (2016, March/April). Beheading, raping and burning: How the Islamic State justifies its actions. Military Review, March-April, 28-35.

Mitchell, H. (2013, December 30). Why does music aid in memorization? A memory expert on why songs get stuck in your head. Retrieved from shorturl.at/kAIUW.

Moutot, M. (2016, January 18). The ISIS "brand" is spreading worldwide, experts say. Retrieved from www.english.alarabiya.net.

Perry, S. \& Long, J. (2016). "Why would anyone sell paradise?" The Islamic State in Iraq and the making of a martyr. Southern Communication Journal, 81(1), 1-17.

Petroff, A. (2015, May 7). ISIS: The most successful terrorist brand ever? Retrieved from shorturl.at/knKQ3.

Phillips, A. (2014). The Islamic State's challenge to international order. Australian Journal of International Affairs, 68(5), 495-498.

Pratkanis, A. \& Aronson, E. (2001). Age of propaganda: The everyday use and abuse of persuasion. New York: Henry Holt.

Roche, J. (2017, July 12). Islamic state and the appropriation of the Crusades - a Medieval historian's take. The Conversation. Retrieved from https://bit.ly/2RZ2NMj.

Rowland, R. \& Theye, K. (2008). The symbolic DNA of terrorism. Communication monographs, 75(1), 52-85.

Segall, L. (2014, September 30). ISIS recruiting tactics: Apple pie and video games. Retrieved from shorturl.at/IMPYZ.

Shahi, A. (2012). Paradoxes of Iranian messianic politics. Digest of Middle East Studies, 21(1), 108-125.

Shubert, A. (2015, April 21). How ISIS controls life, from birth to foosball. Retrieved from shorturl.at/aoqCS. 
Signorelli, J. (2014). Storybranding 2.0. Austin, Tx.: Greenleaf Book Company.

Signorelli, J. (2017). Storybranding 2.0: Creating standout brands through the power of story. Evanston, IL: Story-Lab Productions.

Tome, L. (2015). The Islamic State: Trajectory and reach a year after its self-proclamation as a caliphate. The Journal of International Relations, 6(1), 116-139.

Trofimov, Y. (2016, February 25). How Tunisia became a top source of ISIS recruits: Thousands of Tunisians have gone to fight with Islamic State in Syria, Iraq. Retrieved from https://on.wsj.com/2tuo9Yp.

Trianni, F. (2015, February 5). Inside ISIS and al-Qaeda's battle for brand supremacy. Retrieved from shorturl.at/mtIWX.

Vick, K. (2016, April 11). Losing in battle, ISIS gains by attacking the "gray zone" of the west. Time. Retrieved from https://bit.ly/2Uqi1v6.

Vick, K. (2015, November 23). A more dangerous ISIS is now the ultimate terror group. Time/The Brief. Retrieved from shorturl.at/ly026.

Vogel, L. (2016, February 16). Why are doctors joining ISIS? Canadian Medical Association Journal, 188(3).

Von Drahle, D. (2015, November 30). Beating ISIS: The war against the terror group requires the kind of leadership that has gone missing. Time. Retrieved from https:// bit.ly/370kmzw.

Walt, S. (2015, November/December). ISIS as a revolutionary state: New twist on an old story. Foreign Affairs, 94(6), 42-51.

Warrick, J. (2018a, January 22). "We are in your home": After losses, ISIS steps up campaign to inspire attacks. Washington Post. Retrieved from shorturl.at/kmqHL.

Warrick, J. (2018b, August 19). In fight against ISIS's propaganda machine, raids and online trench warfare: Targeted in police action ISIS's news agency "went down fast," but it came back again and again. Washington Post. Retrieved from shorturl.at/ enqCY.

Yan, H. (2015, March 23). How is ISIS luring westerners? Retrieved from shorturl.at/ oxISO.

Yildirim, A. (2016, March 03). Between anti-Westernism and development: Political Islam and environmentalism. Middle Eastern Studies, 52(2).

Zakaria, R. (2015, January 12). Clicking for ISIS: How the well-meaning public became a handmaiden for terror. The Nation, 300, 22-25.

Zelin, A. Y. (2014). The war between ISIS and al-Queda for supremacy of the global jihadist movement. Research Notes: The Washington Institute for Near East Policy. Retrieved from shorturl.at/bgrLT. 
